\title{
The convergence and divergence of job discretion between occupations and institutional regimes in Europe from 1995 to 2010
}

DOI:

10.1111/joms.12265

\section{Document Version}

Accepted author manuscript

Link to publication record in Manchester Research Explorer

Citation for published version (APA):

Holman, D., \& Rafferty, A. (2017). The convergence and divergence of job discretion between occupations and institutional regimes in Europe from 1995 to 2010. Journal of Management Studies, 55(4), 619-647. https://doi.org/10.1111/joms.12265

Published in:

Journal of Management Studies

\section{Citing this paper}

Please note that where the full-text provided on Manchester Research Explorer is the Author Accepted Manuscript or Proof version this may differ from the final Published version. If citing, it is advised that you check and use the publisher's definitive version.

\section{General rights}

Copyright and moral rights for the publications made accessible in the Research Explorer are retained by the authors and/or other copyright owners and it is a condition of accessing publications that users recognise and abide by the legal requirements associated with these rights.

\section{Takedown policy}

If you believe that this document breaches copyright please refer to the University of Manchester's Takedown Procedures [http://man.ac.uk/04Y6Bo] or contact uml.scholarlycommunications@manchester.ac.uk providing relevant details, so we can investigate your claim.

\section{OPEN ACCESS}


The convergence and divergence of job discretion between occupations and institutional regimes in Europe from 1995 to 2010

\section{David Holman}

Alliance Manchester Business School

University of Manchester

Manchester

M15 6PB

Tel: +44-161-306-3433

email: david.holman@manchester.ac.uk

\section{Anthony Rafferty}

Alliance Manchester Business School

University of Manchester

Manchester

M15 6PB

email: anthony.rafferty@manchester.ac.uk 


\title{
The convergence and divergence of job discretion between occupations and institutional regimes in Europe from 1995 to 2010
}

\begin{abstract}
Drawing on technical change and institutional theories, this paper examines the convergence and divergence of job discretion between occupations and institutional regimes in Europe from 1995-2010. Latent growth modelling of a pseudo-panel data set derived from the European Working Conditions Survey reveals that significantly different rates of change have led to an increasing polarisation of job discretion between occupations and between Nordic and other European countries. Across occupations the findings are in keeping with routinebiased technical change rather than skill-biased technical change theories and suggest that the effects of technical change on job discretion depend largely on whether technology substitutes or complements job tasks. Across countries, the results are in line with employment regime theory, which suggests that institutional differences (particularly employment policies and trade union influence) are driving cross-national variation in job discretion. Overall, a more comprehensive empirical and theoretical understanding is provided of factors shaping change in a key aspect of job quality, namely job discretion.
\end{abstract}

Key words: Europe, institutional regimes, job discretion, routine-biased technical change. 
Growing inequalities in work and employment conditions present a number of challenges for organisations and society (Allmendinger \& Driesch, 2014; Stiglitz, 2013). As inequalities grow, increasing numbers of employees become exposed to poor working conditions, feelings of injustice and social exclusion can develop in those adversely affected and, as a result, employee well-being and commitment may suffer (Bernerth \& Walker, 2012; CohenCharash \& Spector, 2001; Eurofound, 2015; Marescaux, Winne \& Sels, 2013). Furthermore, greater workplace inequalities may restrict managers' ability to achieve a coherent human resource management strategy that creates a strong organisational climate in which employees feel integrated and motivated because inequalities in working conditions make it difficult to implement a common set of human resource practices across all employees and to generate a shared perception among employees of the fairness and therefore appropriateness of human resource practices (Cropanzano, Bowen, \& Gilliland, 2007; Kepes \& Delery, 2006). Given that we lack a clear and comprehensive understanding of whether inequalities in work and employment conditions are indeed growing (i.e., diverging) or are in fact reducing (i.e., converging), it is critical and timely that research focuses on this issue and provides a clearer picture of the trends. Without such an understanding, managers may lack awareness of what is driving the convergence and divergence of working conditions and hence is limiting the likelihood of developing strategies to respond to inequalities in working conditions.

Two theoretical perspectives are typically drawn on to explain the convergence and divergence of work and employment conditions. Theories of technical change (especially skill-biased technical change and routine-biased technical change theories) suggest that convergence and divergence will occur between occupational groups due to the differential impact of computer technology across occupations (Autor, Levy \& Murnane, 2003; Milgrom \& Roberts, 1990). In contrast, institutional theories assert that convergence and divergence 
will occur between countries as a result of cross-national differences in institutional regimes, i.e., systematic configurations of national institutions (Gallie, 2007). Previous studies, for example, suggest that pay is diverging across occupations due to technological change, while working time is converging and diverging across countries due to differences in national institutional regimes (Goos, Manning \& Salomons, 2009, 2011; Tregaskis \& Brewster, 2006).

However, existing research on the convergence and divergence of work and employment conditions is limited in two important ways. First, it has not simultaneously examined changes in working conditions between occupations and between national institutional regimes. This has made it difficult to resolve debates about which factors are most important in driving workplace inequalities and the relative importance of different theories to explaining such changes (Mishel, Schmitt \& Shierholz, 2013; Mouw \& Kalleberg, 2010; Rubery \& Grimshaw, 2001). Second, as existing research in this area has focused on employment conditions (e.g., pay, working time), we know little about whether there are growing inequalities in the characteristics of work itself (e.g., job discretion, task variety) and, as such, whether inequality is growing across a broad or narrow range of work and employment conditions. We therefore focus on job discretion (i.e., the extent to which employees decide how to carry out work tasks and the timing of work tasks, Jackson, Wall, Martin \& Davids, 1993) as it is generally considered to be a key work characteristic because it shapes the effectiveness of operational practices and human resource management systems (Appelbaum, Bailey, Berg \& Kalleberg, 2000; Holman et al., 2005) due to its impact on key employee outcomes such as psychological and physical well-being, job satisfaction, skill development and job performance (Eijckelhof et al., 2013; Humphrey, Nahrgang \& Morgeson, 2007) and its role in determining the experience of other work characteristics, particularly job demands (Karasek \& Theorell, 1990). In sum, to address the theoretical and empirical limitations of previous research, the main aim of this article is to use theories of 
technical change and institutional theory to examine the convergence and divergence of job discretion between occupations and countries.

The paper makes a number of important contributions. By simultaneously testing alternative theoretical perspectives (i.e., theories of technical change and institutional theory), it provides a broader theoretical account of the factors driving the convergence and divergence of working conditions and presents new evidence regarding the relative importance of these theories to explanations of workplace change. In addition, by focusing on changes in job discretion, this paper enriches and expands on accounts of growing inequalities in working conditions, whilst also helping to identify those workers at growing risk of exposure to deleterious working conditions. A further contribution is that we statistically evaluate convergence and divergence by using latent growth modelling of pseudo-panel data (Deaton, 1985; Verbeek \& Vella, 2005) to test whether the long-term trends in job discretion (i.e., rates of change over three or more time points) are statistically different between groups (e.g., occupations, institutional regimes). Convergence or divergence is indicated by significant differences in rates of change between groups and whether the trends indicate greater similarity or dissimilarity over time. This is in contrast to previous studies on the convergence and divergence of job discretion that have only described such changes or only examined change across two-time points (Eurofound, 2009; Gallie, Felstead \& Green, 2004; Lopes, Lagoa \& Calapez, 2014). It is also important to note that the only available data set that currently permits the analysis of the long-term trends in job discretion across both occupations and institutional regimes is the European Working Conditions Survey (EWCS) $)^{\mathrm{i}}$. This is because the EWCS contains data on employee perceptions of working conditions collected from multiple countries across four time points (Eurofound, 2012a). However, the use of this data restricts our analysis to fifteen European countries (the EU-15) ${ }^{\mathrm{ii}}$ from 1995 to 2010. 


\section{Background and Theory}

\section{Defining Convergence and Divergence}

Convergence can be defined as occurring when the trends (i.e., rates of change) in working conditions between two groups indicate greater similarity over time, whereas divergence occurs when trends in working conditions between two groups indicate greater dissimilarity over time. These definitions refer to general patterns of convergence and divergence. More specific patterns of divergence and convergence can be delineated if the general direction of change is also considered, i.e., whether working conditions are improving or declining (Eurofound, 2015). A typology of these specific patterns is shown in Table 1 and examples include 'harmonised improvement' (the convergence and improvement of working conditions) and 'polarized decline' (the divergence and decline of working conditions). In this paper, we focus on general rather than specific patterns of convergence and divergence. This is because the theoretical and empirical aim is to explain changes in job discretion between groups and not whether job discretion is increasing or decreasing. However, as our analyses of convergence and divergence entails testing whether job discretion is improving or declining, the results will illuminate the specific patterns of convergence and divergence in job discretion across Europe.

Insert Table 1 about here

\section{The general convergence and divergence of working conditions}

To explain the convergence and divergence of work and employment conditions, studies often draw on theories of technical change (e.g., SBTC and RBTC) to explain trends between occupations and on institutional theories to explain trends between countries. These theories have been applied successfully to understanding trends in wages (Acemoglu \& Autor, 2010; Autor, Katz \& Krueger, 1998; Davis, 1992; Mishel et al., 2013; Spitz-Oener, 2006) and other 
work and employment conditions such as working time, work organisation and contingent working practices (Eurofound, 2009; Green et al., 2013; Lopes et al., 2014; Olsen, Kalleberg \& Nesheim, 2010; Tregaskis \& Brewster, 2006). In the following, we will build on and use this literature to provide a detailed explanation of why job discretion is likely to converge or diverge between occupations and between countries.

Convergence and divergence of job discretion between occupations Theories of skillbiased technical change (SBTC) and routine-biased technical change (RBTC) assert that working conditions converge or diverge between occupations due to the differential impact of computer technology (Autor et al., 2003). However, each theory predicts a different pattern of convergence and divergence. SBTC theories suggest that job discretion will diverge between two occupational groups, namely high and low-skill occupations. RBTC theories suggest that job discretion will diverge and converge between four occupational groups, with job discretion in routine clerical occupations (e.g., office clerks) diverging from that in nonroutine clerical occupations (e.g., professional roles) but converging with that in routine manual (e.g., assembly workers) and non-routine manual occupations (e.g., craft workers). We now set out the theoretical rationale for these predictions.

According to SBTC perspectives, the introduction of computer technologies over the last forty to fifty years has led to a sustained demand for high-level skills relative to low-level skills and thereby heightened competition in the labour market for highly skilled employees (Acemoglu \& Autor, 2010; Nelson \& Phelps, 1966; Violante, 2008). Managerial responses to competitive labour markets typically entail improving the employment and working conditions for those employees that they struggle to recruit or retain (Boxall \& Purcell, 2011). These changes can include improving working time flexibility, increasing employees' span of responsibility and introducing more flexible methods of working (Appelbaum et al., 2000; Cappelli, 2000), all of which are likely to improve job discretion, whether intended or not 
(Parker \& Wall, 1998). As such, managerial responses to the technologically induced demand for high-skill employees are likely to involve improvements to the work organisation and hence job discretion in high-skill jobs. Another effect of the greater demand for highskill employees is to increase their power in the labour market to obtain preferred working conditions (Guy \& Skott, 2007; Pfeffer \& Konrad, 1991). An important working preference for most employees is high job discretion, as it meets a basic need for self-determination, makes work more interesting and fulfilling, and helps employees to reduce stress and perform more effectively (Kalleberg, 1977; Wrzesniewski \& Dutton, 2001). Many employees therefore attempt to gain greater discretion and control over working procedures and working time (Tims, Bakker \& Derks, 2013). However, the relatively greater labour market power of high-skill employees not only means that their attempts to increase job discretion may be more readily accepted by managers than similar efforts by low-skill employees but also that high-skill employees may have a greater capacity to resist practices that might reduce job discretion such as task simplification or electronic monitoring (Clegg \& Spencer, 2007; Jermier, Knights \& Nord, 1994).

The strategies adopted by managers during the implementation of computer technology can also be biased towards high-skill employees. Research shows that, when introducing computer technologies in high-skill occupations, managers may try to alter work organisation by implementing flatter hierarchies, team-based working or more flexible methods of working (e.g., computer integrated manufacturing) in the belief that these forms of work organisation enable high-skill employees to use computers more effectively (Bresnahan, Brynjolfsson \& Hitt, 2002; Hempell \& Zwick, 2005; Milgrom \& Roberts, 1990). In contrast, when introducing computers into low-skill occupations, managers may prefer to introduce forms of work organisation that simplify work and decrease job discretion, as they believe that this is the most efficient means of organising computer-based work for low-skill 
employees (Braverman, 1974; Knights, Willmott \& Collinson, 1985). As such, one likely consequence of managerial strategies during the implementation of computer technology is to increase job discretion in high-skill occupations relative to that in low-skill occupations.

To summarise, a SBTC perspective provides plausible grounds to expect job discretion in high-skill jobs to diverge from that in low-skill jobs because the introduction of computer technology has increased the need for managers to improve working conditions for high-skill employees and has increased the relative capacity of high-skill employees to secure better working conditions. Divergence in job discretion may also result from managers adopting different strategies during the implementation of computer technology in high and low-skill occupations. Although there is little direct evidence regarding trends in job discretion between high and low-skill occupations, studies have found a positive association between computer technology, higher-order skills and job discretion. This evidence is in keeping with the idea that technical change is skill-biased and that, as a result, job discretion should be greater in high-skill occupations (Eurofound, 2008, 2013; Hempel \& Zwick, 2005; Green, 2009; Spitz-Oener, 2006, 2008). Theories of SBTC therefore provide a strong but as yet untested argument that job discretion should diverge between high and low-skill occupations. Our first hypothesis is:

Hypothesis 1: Job discretion will diverge between high and low-skill occupations. An alternative view of the impact of technical change on working conditions comes from routine-biased technical change theories (RBTC) (Autor et al., 2003). A basic insight that can be derived from RBTC is that the introduction of computer technologies can stimulate the reconfiguration of work roles (i.e., adding, removing or altering work tasks) and thereby influence work characteristics such as job discretion. However, the likelihood of this occurring depends on a) the type of tasks performed, particularly whether the main job tasks are routine or non-routine and cognitive or manual b) whether computers complement or 
substitute for the main job tasks, and c) the social and organisational context of the reconfiguration process. As such, an RBTC perspective suggests that occupations may be categorized into four groups that differ according to the main task performed (i.e., routine cognitive, non-routine cognitive, routine manual, non-routine manual) and that the effects of technical change will vary across these four occupational groups due to task-based differences and result in working conditions such as job discretion converging or diverging between them. We now explain the rationale behind this assertion by focusing on each occupational group in turn.

Occupations that predominantly perform non-routine cognitive tasks (e.g., problemsolving, analysis and managing others) include non-manual or 'clerical' ${ }^{\text {'ii }}$ occupations such as managerial, professional and technical roles (Autor et al., 2003; ILO, 2012). We therefore label these as 'non-routine clerical' occupations. Computer technology complements the non-routine cognitive tasks performed in these occupations, for example by making data analysis easier, but it cannot be a substitute for these tasks. Thus, while the introduction of computer technology may have stimulated some reconfiguration of non-routine clerical roles, it is also likely to have intensified demand for workers with the high-level skills required to perform complex cognitive tasks, and thereby increased the labour market power of workers in non-routine clerical occupations. As a result, it is expected that workers in non-routine clerical occupations will have been able to improve working conditions such as job discretion.

Occupations predominantly performing more routine cognitive tasks (e.g., record keeping, simple calculation) include clerical occupations such as clerks and service workers (Autor et al., 2003). We label these as 'routine clerical' occupations. Organisations have been able to use computer technologies to substitute for some of the routine cognitive tasks done in routine clerical occupations due to technological advances and falling technology costs. This 
has resulted in job losses (Goos et al., 2011) and is likely to have stimulated the reconfiguration of low-skilled clerical roles. Furthermore, over the last twenty to thirty years, the reconfiguration of routine clerical jobs has occurred within the context of increased cost pressures from global competition, as manifest for example through the greater use of international outsourcing and offshoring, which may partly explain why managers have tended to adopt deskilling and task simplification strategies when reconfiguring routine clerical roles, a result of which is to lower job discretion. For example, the introduction of call centre technologies was primarily driven by a desire to reduce costs and led to jobs being lost (e.g., bank clerks) and roles being reconfigured into call centre operator jobs with simpler tasks and much lower job discretion (Holman, 2005). In addition, the capacity of workers in routine clerical occupations to resist deleterious changes to working conditions is likely to have been eroded by the threat of being replaced by computers or of jobs being outsourced or offshored (Brock \& Dobbelaere, 2006; Doellgast \& Greer, 2006; Kalleberg, 2011). This suggests that job discretion will have declined in routine clerical jobs because technological change and competitive global pressures stimulated a reconfiguration process that resulted in deskilling and task simplification that workers in routine clerical jobs lacked the capacity to resist.

Occupations mainly performing non-routine manual tasks (e.g., crafting products, repairing machines and building) include manual occupations such as craft and trade workers. They can therefore be labelled as 'non-routine manual' occupations. Affordable computer technologies are currently unable to do many non-routine manual tasks, thereby limiting the opportunities for computers to complement or substitute for these tasks (Autor et al., 2003). As a consequence, computer technologies are unlikely to have resulted in an extensive reconfiguration of non-routine manual roles, so little change in job discretion in these roles is likely to have occurred. Lastly, occupations that mainly perform routine manual tasks, 
including machine operators and assemblers, can be labelled as 'routine manual' occupations. Computer technology has the potential to substitute for the routine manual tasks performed in these occupations and thus promote the reconfiguration of work roles. But any negative effect of this reconfiguration on job discretion may be greatly limited by the fact that job discretion is already very restricted in these occupations (Eurofound, 2012a; Lopes et al., 2014) such that computer technology is unlikely to have had a substantial negative impact on the level of job discretion in routine manual work.

In summary, RBTC predicts that the impact of computer technology on job discretion should vary between four occupational groups, with the main outcome being a downward trend in job discretion among non-routine clerical jobs. Due to historical differences in job discretion between occupational groups ${ }^{\text {iv }}$, this implies that technological change should result in job discretion diverging between non-routine and routine clerical occupations and converging between routine clerical occupations and both non-routine and routine manual occupations. Based on the theoretical and empirical evidence, we therefore set the following hypothesis.

Hypothesis 2. Job discretion will diverge between non-routine and routine clerical occupations and converge between routine clerical occupations and both nonroutine and routine manual occupations.

\section{Convergence and divergence between institutional regimes A central concern of} institutional theories is to explain how national differences result from cross-national variation in institutional regimes, and two theories are particularly appropriate to the explanation of national differences in work and employment conditions. Varieties of Capitalism (VoC) theory focuses on the institutional arrangements (e.g., collective bargaining structures, training systems) through which firms coordinate their actions to address issues such as industrial relations, training and employee cooperation (Hall \& Soskice, 2001). A 
distinction is made between coordinated regimes (e.g., Denmark, Germany, France) in which firms manage activities through collaborative institutional arrangements and liberal regimes (e.g., the U.K.) in which firms interact predominantly through competitive markets and formal contracting. In contrast, employment regime theory focuses on how the relative power of employers and workers is mediated by the state (Gallie, 2007, p16) and the institutions involved in this process such as financial, educational and welfare systems, as well as national employment policies and trade unions (Esping-Anderson, 1990; Gallie, 2007; Korpi, 2006). Four institutional regimes are distinguished, namely social democratic (Denmark, Sweden, Finland), continental (Austria, Belgium; France, Germany, Netherlands, Luxembourg), liberal (U.K., Ireland) and southern European (Greece, Italy, Portugal, Spain). Although both theories can be used to explain the convergence and divergence of job discretion between countries, we draw on employment regime theory for a number of reasons. First, the focus in employment regime theory on the relative power of employer and worker offers a broader and more comprehensive account of how workplace conditions are shaped, and one that is more in keeping with what is known about the multiple influences on job discretion (Parker \& Wall, 1998). Second, employment regime theory identifies two institutional characteristics that influence working conditions, namely, national employment policies and trade unions and provides an account that can be drawn on to explain how institutional characteristics will affect job discretion (Gallie, 2007). Third, employment regime theory proposes a more comprehensive and nuanced account of European institutional regimes, as it includes southern European regimes and distinguishes between social democratic and continental regimes. Fourth, recent analyses show working conditions to vary between European countries in a way in that is more consistent with employment regime theory than VoC, particularly with regard to differences between Nordic/social democratic countries and continental European countries (Dobbin \& Boychuk, 1999; Gallie, 2007; 
Goergen, Brewster \& Wood, 2009; Holman, Frenkel, Sørensen \& Wood, 2009). For example, Holman (2013) found significant differences in the proportion of high-quality jobs (i.e., jobs with better working conditions, security and flexibility, development opportunities, and representation) between countries with social democratic, continental, liberal and southern European regimes.

As noted, employment regime theory identifies national employment policies and trade unions as institutional characteristics that may influence working conditions such as job discretion. National employment policies include employment protection legislation (e.g., laws concerned with the ease of hiring and firing), welfare provision (e.g., unemployment and sickness benefits), full employment policies and active labour market policies (e.g., subsidized employment, training and re-training policies, and job search assistance). These institutional characteristics may affect job discretion in different ways. For example, strict employment protection legislation that guards against unfair dismissal or extensive welfare provision that lessens the perceived risks of job loss may increase the willingness of employees to resist practices deemed deleterious to well-being, such as job simplification. Alternatively, full-employment, active labour market policies may tighten the labour market and encourage employers to improve working conditions as a means of attracting and retaining employees (Dobbin \& Boychuk, 1999; Gustavson, 2007; Wallerstein, 1999). A greater right to re-training can also support workforce adaptation to changes in the demand for skills linked to technological change. Higher wages through minimum wage legislation or collective arrangements provide disincentives towards investment in low-skill and low-value added economic activities whilst incentivising investment in high-skill and high-value added ones. This may occur where higher wage costs relative to competitors in other countries preclude market entry or cost leadership strategies in some globally competitive markets (Mclaughlin, 2009). A tighter labour market may also make employers more willing to train 
because returns on such investments are more likely (Cappelli et al., 1997; Finegold and Soskice, 1988). In turn, the higher skills of employees may permit the design of more complex jobs and result in higher job discretion (Prais, Jarvis \& Wagner, 1989).

With regard to trade unions, relevant institutional characteristics include the extent to which unions participate in decision-making within and between organisations and sectors (e.g., works councils, wage coordination with employer organisations) and the extent of trade union membership. Trade unions that participate in organisational decision-making and have higher membership should be better placed to achieve their aims such as promoting skills and resisting job standardization (often because this protects members' wages) and as such will be more likely to have a positive effect on job discretion (Culpepper \& Thelen, 2007; Esser \& Olsen, 2012; Gallie, 2000; Kristensen \& Lilja, 2010).

Although there may be some differences at the sectoral level in trade union activity within countries (Bechter, Brandl \& Meardi, 2012), employment policies and dominant modes of industrial relations nonetheless vary systematically between institutional regimes (EspingAnderson, 1990; Gallie, 2007, 2013). Social democratic regimes tend to have more extensive welfare benefits and greater investment in active labour market and training policies, enabling a greater focus on human capital development and re-training compared to lower investment 'work-first' approaches typically found in liberal regimes. Social democratic regimes also have more influential trade unions due to greater involvement in organisational and governmental decision-making (e.g., national wage coordination), a greater proportion of employees covered by collective bargaining, and high union membership levels. The comparatively large size of the public sector furthermore provides a source of high-skill employment, particularly for more highly educated women. By comparison, in continental regimes, trade unions have less influence as they typically have a more consultative role within organizations, their influence is partly dependent upon the party of government, and 
union density is lower (Gallie, 2013). A further difference, reflecting sectoral and occupational variation, is that union membership and influence, as well as employment protection legislation, tends to be weaker among employees on non-standard contracts and in small organisations. Compared with both social democratic and continental regimes, within liberal regimes, trade union participation in decision-making within firms or government is very limited and largely restricted to the public sector or ex-public sector (Hyman, 2001) and union density is low (Gallie, 2013). Furthermore, employment and social protection is weaker and more residual than in social democratic and continental regimes and there is very little direct state intervention regarding employment levels, with market-based mechanisms preferred by government and employers (Gallie, 2007). The southern European regime is often typified as a more 'hybrid or 'mixed' model sharing features of both the more coordinated and liberal market economies and is associated with more state-centred production regimes (Molina \& Rhodes, 2007). Here employment protection is present creating low flexibility, but there may be a marked duality between the rights and employment security afforded to core and peripheral workforces (European Commission, 2008). Industrial relations arrangements are often fragmented between modes of production, sectors, geographies, or by political affiliation, and trade unions have variable but often little influence and involvement in decision-making within firms (Amable, 2003).

Given the differences in institutional regimes across Europe, institutional regimes should vary in the extent to which they foster job discretion over time. For example, influential trade unions and active labour market policies may result in the steady accumulation of job discretion. These institutional characteristics may also act to protect job discretion from various downward pressures that have increased in intensity over the last thirty years. These include organisational responses to the increased cost pressures of global competition that involve work simplification and deskilling (Eurofound, 2012b; Greenan et al., 2013) and the 
spread of performance monitoring and lean manufacturing practices across service and manufacturing sectors (Delbridge, 2005; Holman et al., 2009). In particular, social democratic regimes should be the most effective at fostering and protecting job discretion, followed by continental regimes and then liberal regimes. Southern European regimes are likely to be the least effective at fostering and protecting job discretion. As a result job discretion should diverge between institutional regimes in Europe over time, with greater divergence when institutional differences are more pronounced, e.g., between social democratic regimes and southern European regimes.

Hypothesis 3. Job discretion will diverge between institutional regimes in Europe.

In summary, it is proposed that the convergence and divergence of job discretion will occur concurrently across occupations and institutional regimes in EU15 countries.

\section{Method}

\section{Sample}

The sample used in this study was drawn from four waves (1995-2010) of the quinquennial European Working Conditions Survey (EWCS). The EWCS obtains a representative sample of employees in each country (typically about 1000) using a stratified and clustered design with a 'random walk'. The survey is administered during a face-to-face interview in the respondent's own home in which the respondent is asked about various aspects of his or her job (Eurofound, 2007). The sample covers fifteen European countries and the sample at each time point is 15816 (1995), 21507 (2000), 14716 (2005) and 22152 (2010).

The EWCS is a repeated-cross sectional survey. To enable a longitudinal analysis of the data from this survey we constructed a pseudo-panel data set by forming cohorts around particular criteria and treating the average score of the cohort as the observation (Deaton, 1985). The cohorts in this study were based on $15 \mathrm{EU}$ countries and nine ISCO occupational 
categories (the armed forces category was excluded due to small cohort sizes). These criteria produce a sample of sufficient size $(n=135)$ and with sufficiently large cohort sizes (Curran, Obeidat \& Losardo, 2010; Verbeek \& Vella, 2005) to enable the comparative analysis of trends in job discretion between occupational groups and institutional regimes using latent growth modelling. When creating cohort means, a post-stratification weight was used to ensure scores reflect the working population in each country.

\section{Measures}

Dependent variable Job discretion was a three-item measure concerning the extent to which an employee has control over how they do their job and the timing of their job. The items are: Are you able to choose or change your order of tasks? Are you able to choose or change your methods of work? Are you able to choose or change your speed or rate of work? The response scale for each item was No $=0$ and Yes $=1$. The mean of the three items was calculated and standardized to a score of 0-100 to facilitate interpretation.

To test the factorial validity of the job discretion measure we conducted a CFA on the total employee-level sample data $(n=73941)$. The results showed that each item loaded significantly, with all items loading over .76, and that the model had an excellent fit to the data $\left(\chi^{2}=78.87, \mathrm{RMSEA}=.032, \mathrm{CFI}=1.00, \mathrm{SRMR}=.001\right)$. The Cronbach alpha was .85 .

Independent variables Two measures of occupational groups were created. To test SBTC, we created a measure of high and low-skill occupations. According to internationally accepted standards, occupations can be graded according to four skill levels (ILO, 2012). ISCO categories 1-3 (e.g., managers, professionals, technicians) are classed as having the two highest levels of skill (Levels 3 and 4), while ISCO categories 4-9 (e.g., clerical workers, craft workers, elementary occupations) are classed as having the two lowest levels of skill (Levels 1 and 2). As such, we created a measure of high-skill occupations (ISCO 1-3) and low-skill occupations (ISCO 4-9) that was scored 1-0. 
To test RBTC, we created four dummy variables to represent non-routine clerical, routine clerical, non-routine manual and routine manual occupational groups. Each occupation (ISCO 1-9) was placed into one of these occupational groups based on the extent to which it had high or low task routineness and whether the main task was manual or clerical. To measure task routineness, we used an item from the EWCS concerning task complexity ('Does your job involve complex tasks', response $0=$ No, $1=$ Yes) and categorized occupations based on whether they were higher or lower than the mean score $(\mathrm{M}=0.58, \mathrm{~N}=$ 73584). In accordance with ISCO categories, ISCO1-5 occupations were classified as clerical and ISCO6-9 were classified as manual. This method resulted in: non-routine clerical occupations (Mean task complexity $=.73$ ) including ISCO1 (Legislators, senior officials and managers, $\mathrm{M}=.68$ ), ISCO2 (Professionals, $\mathrm{M}=.78$ ) and ISCO3 (Technicians, $\mathrm{M}=.70)$; routine clerical occupations $(\mathrm{M}=.48)$ including ISCO4 (Clerks, $\mathrm{M}=.56)$ and ISCO5 (Service and Sales, $M=.40)$; non-routine manual occupations $(M=.66)$ including ISCO7 (Craft and Related Trades, $\mathrm{M}=.66)$; and routine manual occupations $(\mathrm{M}=.37)$ including ISCO6 (Skilled Agricultural and Fishery, $\mathrm{M}=.47$ ), ISCO8 (Plant and machine operators, $\mathrm{M}=.44$ ), and ISCO9 (Elementary Occupations, $\mathrm{M}=.29$ ). The task complexity of each non-routine occupation was significantly higher than that of each routine occupation ( $p$ $<.05, \mathrm{~N}=73584)$, thereby confirming that the task differences in routineness between the occupational groups are in accord with the assumptions of RBTC. As a robustness check on this method of classification we categorised occupations using a related measure of cognitive demands (Eurofound, 2015), which can also be viewed as a measure of job complexity. The three-item measure includes the item on task complexity as well as items on solving unforeseen problems (Does your main paid job involve solving unforeseen problems on your own?, response $0=$ No, $1=$ Yes) and learning new things (does your main paid job involve learning new things?, response $0=$ No, $1=$ Yes). Using this measure in the same manner 
$($ Mean $=.71)$ produces the same classification of occupations: non-routine clerical occupations (Mean $=.83$ ) including ISCO1 (Legislators, senior officials and managers, $\mathrm{M}=$ .80), ISCO2 (Professionals, $\mathrm{M}=.87$ ) and ISCO3 (Technicians, $\mathrm{M}=.81$ ); routine clerical occupations $(\mathrm{M}=.65)$ including ISCO4 (Clerks, $\mathrm{M}=.70)$ and ISCO5 (Service and Sales, $\mathrm{M}$ $=.62)$; non-routine manual occupations $(\mathrm{M}=.73)$ including ISCO7 (Craft and Related Trades, $\mathrm{M}=.73)$; and routine manual occupations $(\mathrm{M}=.52)$ including ISCO6 (Skilled Agricultural and Fishery, $\mathrm{M}=.63$ ), ISCO8 (Plant and machine operators, $\mathrm{M}=.57$ ), and ISCO9 (Elementary Occupations, $\mathrm{M}=.45$ ).

Other methods of classifying occupations have been used in the RBTC literature, particularly that developed by Autor et al. (2003) which is based on an assessment of job tasks in America (i.e., DOT classifications). While suitable for the analytical purposes of Autor et al. (2003), the appropriateness of this method when classifying European jobs over the last twenty years has been questioned, as has its ability to accurately capture job routineness by measuring task abilities such as finger dexterity and task activities such as setting limits, tolerances and standards (Marcolin, Miroudot \& Squicciarini, 2016). The method of classifying occupations in this paper therefore seems preferable as it categorizes individual European jobs based on a contemporary and concurrent assessment of a job using a fairly direct measure of routineness and complexity.

The institutional regime of a country was measured using four dummy variables with countries classified as social democratic (Denmark, Sweden, Finland), continental (Austria, Belgium, France, Germany, Netherlands, Luxembourg), liberal (U.K., Ireland) or southern European (Greece, Italy, Portugal, Spain). We base this classification on the work of Gallie (2007, 2013) but note the considerable debate about the positioning of countries within this institutional regime classification, particularly with regard to the Netherlands (Ferragina et al., 2014). In keeping with Gallie (2013), we classify the Netherlands as having a continental 
regime, as it is similar to other continental regime countries with regard to the trade union and employment policy characteristics deemed significant in this paper. Thus, in the Netherlands, as with other continental regimes, the proportion of employees covered by collective bargaining is relatively high, union density is relatively low, and employment policies such as active labour market programmes and employment protection legislation are fairly extensive (Amable, 2003). However, it must be noted that with regard to some institutional indicators, such as a dependence on market-based finance, the Netherlands has similarities with liberal regimes, but these are not relevant to the theoretical arguments presented in this paper (Amable, 2003).

Control variables Age, gender, service sector and public sector were used as time-variant controls in the latent growth modelling. Scores represent the proportion of employees in a cohort who were female, worked in the service sector, or public sector. Scores for age represented the mean age of the cohort. These variables were used to control for the effects of key changes in the workforce, e.g., an aging workforce, increasing female participation, changes in sector size.

\section{Analysis}

The main analysis was performed using latent growth modelling in Mplus, a key strength of which is the ability to model and test the rates of change in a variable over three or more time points (Kaplan, 2008; Muthén \& Muthén, 2010). This method is particularly suited to the analysis of convergence and divergence as it can be used to establish whether, between two groups, the rate of change across three or more time points is significantly different. Convergence or divergence is indicated by a significant difference and whether the trends indicate greater similarity or dissimilarity over time. Although occupational cohorts were clustered within countries, a multilevel latent growth analysis was not possible as the number 
of parameters in a model typically exceeded the number of clusters $(n=15)$ making parameter estimates unreliable (Muthén \& Muthén, 2010).

The latent growth modelling had two stages. In the first stage, a baseline growth model (Model 1) was constructed to identify the optimal functional form of the growth trajectory (Curran et al., 2010). To find the optimal growth function it is generally recommended that a linear growth function (i.e., a constant rate of change across time) is compared against a range of other growth functions, including those based on empirical data (Grimm \& Ram, 2009; Kaplan, 2008). We therefore compared a model with a linear growth function (i.e., time scores estimated as $\mathrm{b} t=0,1,2,3)$ and a model with an exponential growth function (time scores estimated as $\mathrm{b} t=0,0.69,1.10,1.39)$. We also compared these models with a third model in which the growth function was based on previous empirical data indicating that job discretion in the EU-15 declined steadily from 1995 to 2005 and remained unchanged from 2005 to 2010 (Lopes et al., 2014). The growth function in this model therefore included linear change from time 1 to 3 and no change from time 3 to 4 (time scores estimated as $b_{t=}$ $0,1,2,2)$. Model fit was assessed using a range of fit indices including the root mean squared error of approximation (RMSEA), the standardized root mean squared residual (SRMR) and the comparative fit index (CFI). Benchmarks for good model fit are indicated by values of RMSEA $<.08$, SRMR $<.06$, and CFI $>.95$ (Hu \& Bentler, 1999). The best fitting model is then used to identify whether the rate of change (typically called the slope) is significant. The model also shows whether the slope is significantly related to the intercept, i.e., if the rate of change differs according to the initial level of job discretion. When this information is combined with knowledge about the direction of change it is possible to make inferences about the general nature of convergence or divergence across the whole sample. For example, job discretion would be converging across all employees if the decline in job discretion is faster in jobs with initially higher levels of job discretion. In this and all 
subsequent models, error variances were correlated and the data was weighted to account for differences in cohort sample size (Deaton, 1985; Verbeek \& Vella, 2005). The final part of stage 1 was to create Model 1a in which the time-variant covariates (age, gender, service sector and public sector) were added and correlated with the time-appropriate job discretion variable (e.g., Time 1 Age correlated with Time 1 Job Discretion) and other covariates (e.g., Time 1 Age with Time 1 Gender).

In stage 2, we used Model 1a as the basis on which to test the study hypotheses. To examine Hypothesis 1, whether rates of change differ between high and low-skill occupations, we added the binary measure of high and-low skill occupations (Model 2). In this and all subsequent models, the independent variables were correlated with time-variant covariates to reduce potential biases (Ferrer-i-Carbonell \& Frijters, 2004). To test Hypotheses 2, concerning differential rates of change between the four occupational groups (routine clerical, non-routine clerical etc.), we constructed a series of models in which three occupational group dummy variables were included and one occupational group dummy variable was omitted to act as the referent (Models 3a-3d). A significant parameter coefficient for the slope of the occupational group dummy means that the rates of change between this variable and the referent variable are significantly different. Repeating the analysis with each occupational group as the referent enables the rates of change to be compared between all four occupational groups. To test Hypothesis 3, concerning differential rates of change between institutional regimes, we constructed a series of models in which three dummy coded institutional regime variables were included with one regime omitted to act as the referent (Models 4a-4d). Models 4a-4d also included the four occupational group variables so that the concurrent effects of occupations and institutional regimes on rates of change in job discretion can be tested and thereby reveal whether the effects of occupations and institutional regimes are additive or not. 


\section{Results}

The mean scores for the main study variables and their correlations based on the pseudopanel data are shown in Table 2. Recall that the first stage in the analysis was to establish the best fitting baseline growth model by comparing three models (linear, exponential, empirical). The empirical model had a very good fit to the data $\left(\chi^{2}=12.20, \mathrm{df}=7, \mathrm{CFI}=.99\right.$, RMSEA $=.07$, SRMR $=.04)$. In comparison, the linear model had a slightly worse fit $\left(\chi^{2}=\right.$ 13.06, $\mathrm{df}=7, \mathrm{CFI}=.99, \mathrm{RMSEA}=.08, \mathrm{SRMR}=.05)$, while the exponential model had a similar level of fit $\left(\chi^{2}=11.76, \mathrm{df}=7, \mathrm{CFI}=.99, \mathrm{RMSEA}=.07, \mathrm{SRMR}=.04\right)$. However, the latent covariance matrix of the exponential model was not positive definite, indicating slope misspecification. The empirical model was therefore chosen as the baseline model (Model 1). In this model, the rate of change in job discretion is linear from 1995 to 2005 and flat from 2005 to 2010. Table 4 shows that the slope in this model was negative and significant $(s=-1.13, p<.01)$. This indicates a significant downward trend in job discretion across the EU15 from 1995 to 2010 . However, the intercept was not significantly related to the slope ( $r$ $=2.10, n . s$.$) , which means that there was no general convergence or divergence of job$ discretion across all employees. The last part of stage 1 involved adding the time-variant covariates of age, gender, service sector and public sector to create Model 1a. The fit of Model 1a was very good $\left(\chi^{2}=21.90, \mathrm{df}=23, \mathrm{CFI}=.99, \mathrm{RMSEA}=.00, \mathrm{SRMR}=.01\right)$ and only age was significantly related to job discretion at each time point. The negative slope of job discretion was not significant $(s=-1.99, n s$. $)$ after controls had been added.

Insert Table 2 about here

The second stage of the analysis was to test the study hypotheses, which were concerned with the convergence and divergence of job discretion between occupational groups and institutional regimes. The adjusted mean scores of the occupational groups and institutional 
regimes at each time point are shown in Table 3 and plotted in Figures 1a-1c (Means scores in Table 3 and Figures 1 and 2 are adjusted by age, gender, public sector, service sector and, when appropriate, by institutional regime and occupation). The results of the models used to test the hypotheses are shown in Table 4. Hypothesis 1 asserted that job discretion would diverge between high and low skill occupations. Based on the figures in Table 3 (illustrated in Figure 1a), it can be observed that job discretion remained at a similar level in high-skill occupations from 1995 to 2010 but decreased in low-skill occupations over this period. However, the results for Model 2a shown in Table $4\left(\chi^{2}=68.59, \mathrm{df}=57, \mathrm{CFI}=.97\right.$, RMSEA $=.04, \mathrm{SRMR}=.03)$ indicate that rate of change of job discretion in high-skill occupations was not significantly different to the rate of change in low-skill occupations $(s=.16, n s$. $)$. As such, there is no evidence for the divergence of job discretion between high and low-skill occupations. Hypothesis 1 is not supported. However, the classification of occupations into high and low-skill groups may have obscured differences that may be discerned by using a more fine-grained classification of occupational skill. As a robustness check, we therefore compared rates of change between the four main occupational skill levels as defined in the ISCO. They are: Skill level 4 (High Skill) including ISCO1 (e.g., Legislators) and ISCO2 (Professionals); Skill level 3 including ISCO3 (Technicians); Skill level 2 including ISCO4 (Clerks); and Skill Level 1 that includes ISCO5-9, e.g., service and sales, craft, skilled agricultural, plant and machine operators and elementary occupations. No significant differences in rates of change in job discretion were found between these four groups. (Full results are available from the first author on request).

Insert Table 3 about here

Insert Figures 1 and 2 about here 
Hypothesis 2 concerned the convergence and divergence of job discretion between four occupational groups classified in accordance with RBTC, i.e., non-routine and routine clerical, non-routine and routine manual. An inspection of the mean scores of these occupational groups (see Table 3 and Figure 1b) shows that job discretion declined in routine clerical occupations and was relatively stable in all other occupational groups. The resulting pattern of convergence and divergence is in keeping with that proposed in Hypothesis 2, namely, that the level of job discretion in routine clerical occupations diverges from that in non-routine clerical occupations and converges with that in manual occupations. However, the results for the tests of Models 3a-d shown in Table $4\left(\chi^{2}=78.62, \mathrm{df}=61, \mathrm{CFI}=.97\right.$, $\mathrm{RMSEA}=.05, \mathrm{SRMR}=.03$ ) indicate that the rate of change in job discretion among routine clerical roles was not significantly different to that in non-routine clerical roles $(s=-1.93, n s$. $)$ or non-routine manual roles $(s=-3.36, n s$.) but was significantly different to the rate of change in routine manual roles $(s=-3.26, p<.05)$. This indicates that the level of job discretion in routine clerical jobs has declined towards that in routine manual jobs, resulting in the convergence of job discretion between these two occupational groups. The results for Models 3a-3d only provide partial support for Hypothesis 2.

Stronger support for Hypothesis 2 comes from the analysis of Models 4a-d (see Table 4) that includes both occupational and institutional regime variables $\left(\chi^{2}=88.91, \mathrm{df}=67, \mathrm{CFI}=\right.$ $.96, \mathrm{RMSEA}=.05, \mathrm{SRMR}=.02$ ). When the effects of institutional regimes are accounted for, the results from Models $4 \mathrm{a}-4 \mathrm{~d}$ show that the decline in routine clerical roles was significantly faster than the rate of change in non-routine clerical roles $(s=-2.80, p<.05)$, non-routine manual roles $(s=-3.09, p<.05)$ and routine manual roles $(s=-3.35, p<.01)$. These findings support Hypothesis 2 as they indicate that job discretion has diverged between non-routine and routine clerical occupations and converged between routine clerical occupations and non-routine and routine manual occupations. Furthermore, these findings do 
not appear to be an artefact of using a more fine-grained classification of occupations (that may be more likely to show differences between groups), as no significant differences were found when rates of changes were compared between the four occupational groups classified by skill level.

Insert Table 4 about here

Hypothesis 3 proposed that job discretion would diverge between institutional regimes. The mean scores in Table 3 (see also Figure 1c) reveal that the level of job discretion is relatively stable in social democratic regimes, has a downward trend in continental and liberal regimes, and has declined in southern European regimes but with some recovery from 2005 to 2010. The results for the tests of Models 4a-d shown in Table 4 indicate that the rate of change in social democratic regimes was significantly different to that in continental $(s=$ $2.56, p<.01)$, liberal $(s=3.40, p<.01)$ and southern European regimes $(s=1.92, p<.05)$ and that there were no other significant differences in the rate of change between institutional regimes. This pattern of results indicates that, although the level of job discretion in social democratic regimes has diverged from that in all other regimes, there has been no convergence or divergence between continental, liberal and southern European regimes. Hypothesis 3 is partially supported.

The findings also show that the four occupational groups accounted for $43 \%$ of the rate of change in job discretion, while the institutional regimes accounted for an additional $26 \%$ of the rate of change in job discretion. These results suggest that occupations and institutions have independent effects on the rate of change in job discretion. Furthermore, some variation across institutional regimes in the divergence and convergence between occupations is suggested by the fact that the differences in trends between occupational groups became significant after controlling for institutional regime. Indeed, an inspection of the trends in job 
discretion across each occupational groups within each institutional regime (see Figures 2a2d) suggests that, although the general pattern of change between occupational groups is fairly consistent across all institutional regimes, there are different rates of convergence and divergence in social democratic regimes due to the apparent slower decline of job discretion in routine clerical occupations. However, we were unable to compare rates of convergence and divergence in occupational groups across institutional regimes, as the models used in the multigroup procedure required to test this would have too many parameters in relation to the sample size, such that robust standard errors could not be produced.

\section{Insert Figure 2 about here}

\section{Discussion}

The main aim of this paper was to use theories of technical change and institutional theory to examine the convergence and divergence of job discretion between occupations and between EU-15 countries from 1995 to 2010. The findings make a number of important empirical and theoretical contributions to our understanding of workplace change and inequality.

Empirically, the results provide new insights that reveal the polarization of job discretion, and hence growing inequalities in working conditions, across both occupations and institutional regimes in Europe. If the decline in job discretion is also considered, these changes can be more accurately described as a 'polarized decline'. Among occupations, the polarized decline was characterised by the level of job discretion in non-routine clerical occupations becoming increasingly different from that in routine clerical occupations, and among institutional regimes it was characterised by the faster decline of job discretion in continental, liberal and southern European regimes compared to that in social democratic regimes. When combined with the insights from other studies, for example those indicating 
similar changes in pay across occupations (Autor, Levy \& Murnane, 2003), the findings suggest growing inequalities across key work and employment conditions. Moreover, these changes may prove problematic for organisations, as employees may perceive the growing disparities in job discretion as unfair, which in turn may lower their well-being and commitment (Berneth \& Walker, 2012; Cohen-Charash \& Spector, 2001). For example, Mareseaux, De Winne and Sels (2013) found that employee's perceived disparities in working conditions (including job discretion) were negatively related to organisational commitment. Their results also suggest that inequalities in working conditions may have more deleterious consequences for organisations than inequalities in pay, as perceived disparities in working conditions had stronger negative effects on commitment than those resulting from perceived disparities in pay, which might occur because disparities in pay can be more easily justified on the basis of skill differences or external market conditions.

The polarization of job discretion may also incur other problems for organisations by making it increasingly difficult to pursue particular HRM strategies. One perspective in the strategic HRM literature is that a single HRM system, with HR policies and practices common to all employees, is advantageous because it helps to create the perception of a shared organisational climate that guides employee behaviour and makes employees feel integrated and motivated (Kepes \& Delery, 2006). The polarization of job discretion is likely to make it more difficult for organisations to pursue such an approach to HRM, as polarization may restrict managers' ability to achieve a unified system of HRM and inhibit the perception of a shared organisational climate (Skarlicki \& Folger, 1997). These difficulties may be particularly acute when managers are seeking to adopt a high-involvement approach to HRM that is predicated on high levels of job discretion across all employees (Lawler, 1986). In response, managers may need to take a more active approach to reducing discrepancies in working conditions through, for instance, job redesign interventions (Parker 
\& Wall, 1999). However, the growing polarization of job discretion may be less problematic for organisations pursuing a differentiated HRM strategy in which, for example, a highinvolvement HRM approach is used for high-skilled employees with more firm-specific skills requirements and a low-involvement HRM approach is used for low-skilled employees (Lepak \& Snell, 1999). Indeed, growing inequalities in working conditions may make it easier for organisations to adopt a differentiated approach to HRM, although this may present managers with a new set of challenges concerned with justifying the approach to employees and dealing with any resulting negative consequences due to a lack of perceived fairness in working conditions such as low employee commitment (Kepes \& Delery, 2006).

Our results also reveal that job discretion has remained at a relatively low level for many employees (e.g., manual employees) and has declined for many others (e.g., non-routine clerical employees). The significance of this should not be underestimated. Low job discretion can have particularly deleterious effects across a range of employee outcomes such as psychological well-being, physical health, innovation and performance (Humphrey et al., 2007) and it can reduce the possibilities for growth and development (Holman \& Wall, 2002) and strengthen the negative effects of workplace demands (Karasek \& Theorell, 1990). Overall, the changes in job discretion that have occurred in the EU-15 from 1995 to 2010 should be of particular concern to policy makers, employers and social partners because they suggest that current organisational and institutional arrangements do not foster job discretion for a significant number of employees, and are widening inequalities in working conditions.

Theoretically, this paper makes a number of important contributions to the literature on workplace change and inequality. First, the results suggest that routine-biased theories of technical change (RBTC) provide a better account of the convergence and divergence of job discretion than skill-biased theories of technical change (SBTC). Contrary to SBTC, there was no significant divergence in job discretion between high and low-skill occupations (or 
between a more fine-grained skill-based classification of occupational groups), which implies that the effects of technical change do not simply depend on the skill level of a job. Rather, the pattern of convergence and divergence was consistent with RBTC, as job discretion diverged significantly between non-routine and routine clerical occupations and converged significantly between routine clerical and manual occupations (although only after the effects of institutions had been accounted for). This supports a key idea in RBTC, namely, that the effects of technological change on job discretion depends on the extent to which technology can substitute or complement the main job tasks.

Although the findings from this study support RBTC, they shed less light on the mechanisms through which technical change affects specific working conditions such as job discretion. This is because our analyses did not examine the extent to which the divergence and convergence of job discretion between occupational groups was shaped, for example, by managerial strategies or employee actions. However, the relative decline of job discretion in routine clerical workers does imply that the effects of technical change on job discretion within organisations may occur primarily through two mechanisms. The first concerns the technology-induced reconfiguration of routine clerical roles, which managers use as an opportunity to deskill and simplify routine clerical jobs as a means of reducing costs. The second is that the threat of being replaced by computers erodes the capacity of workers in routine clerical roles to secure better working conditions or resist deleterious changes. The other proposed mechanisms through which technical change might affect job discretion, namely, those occurring in non-routine clerical roles, appear to be less well supported by the evidence, as job discretion remained fairly static in these roles. The lack of change in job discretion among non-routine clerical jobs might have occurred because the introduction of computer technology has not increased the power of workers in non-routine clerical jobs to secure better working conditions, contrary to RBTC, and this may be because the supply of 
skilled workers has outstripped demand (Maselli, 2012). But other interpretations are possible. For example, computer technologies may have increased the power of workers in non-routine clerical jobs but they may have used it to secure better pay not more job discretion. Alternatively, workers in non-routine clerical jobs may have used their increased labour market power to secure greater job discretion but this has simply buffered downward pressures on job discretion from, for example, greater work surveillance (ErikssonZetterquist, Lindberg \& Styhre, 2009; Guy \& Skott, 2008). It can also be noted that the level of job discretion in routine manual occupations decreased and then recovered from 1995 to 2005. This pattern is not entirely in keeping with the arguments presented earlier in the discussion of RBTC, namely, that information technology would have little effect on job discretion in routine manual occupations due to a flooring effect. However, the reason for the dip in the level of job discretion over this period is not clear, particularly from the analyses conducted.

A further contribution is to provide new empirical evidence that deepens our theoretical understanding of how institutional regimes shape job discretion. The findings show that job discretion in social democratic regimes has diverged from that in continental, liberal and southern European institutional regimes due to the relatively faster decline of job discretion in these regimes. Although this divergence is in keeping with employment regime theory, the failure to find divergences between continental, liberal and southern European regimes is not. Indeed, employment regime theory suggests that cross-national differences in institutions (particularly trade union influence and national employment policies) should result in job discretion diverging between all types of institutional regime in Europe. This may indicate that employment regime theory fails to offer a compelling explanation of cross-national divergence in job discretion because, for example, it does not correctly characterise institutional differences between countries. But such a conclusion seems premature given the 
support for employment regime theory's characterisation of institutional regimes and the evidence for this theory from other studies (Amable, 2003; Gallie, 2007; Goergen et al., 2009; Holman, 2013; Tahlin, 2007). One explanation for the pattern of results (i.e., divergence from social democratic regimes, no difference between other regimes) is that, while the extent of trade union influence differs between institutional regimes, trade unions also differ in how that influence is used. For instance, studies show that trade unions in social democratic regimes seek to promote better forms of work organisation through collective agreements, policy initiatives and collaborations with governmental and employer organisations to a far greater extent than trade unions in other European regimes (Gallie, 2007; Sørensen, Doellgast, \& Bojesen, 2014; Sørensen \& Weinkopf, 2009). There is also evidence that trade unions in liberal regimes can prevent improvements in work organisation due to fears that such changes may decrease employee pay or union bargaining power (Hyman, 2001; Kelly, 1989). Consequently, job discretion may diverge between social democratic regimes and other European regimes because trade unions in social democratic regimes use their greater influence to improve work organisation, whereas trade unions in other regimes use their more limited influence to achieve other objectives.

Another contribution is to offer a more comprehensive account of change in job discretion across Europe by drawing on RBTC theory and employment regime theory. The findings suggest that RBTC and employment regime theory provide complementary rather than competitive accounts of workplace change because significant differences in the rate of change in job discretion were found between occupations and between institutional regimes when tested concurrently (Goos et al., 2011; Mishel et al., 2013; Mouw \& Kalleberg, 2010; Rubery \& Grimshaw, 2001). This implies that the effects of technical change and institutional regimes on job discretion are additive. Additive effects could occur, for example, because both technical change and institutional characteristics independently affect 
the capacity of employees to obtain greater job discretion. Thus, on the basis of the results, RBTC theory appears to offer a stronger account of the convergence and divergence of job discretion than institutional theory, as occupations accounted for relatively more variance in the rate of change that institutional regimes. This may not be that surprising given that occupational effects are likely to be more distal than institutional effects. But as these findings are specific to job discretion, studies on other working practices are needed before more general conclusions can be drawn regarding the relative importance of RBTC and institutional theories to accounts of workplace change. Furthermore, we were unable to examine whether institutions play a role in moderating the effects of technical change, although this was indicated by the possible slower decline of job discretion in routine clerical occupations across social democratic regimes. Thus our analysis may not have fully captured the strength of institutional effects.

The findings are also relevant for strategic HRM theories concerned with the factors shaping the adoption and implementation of human resource practices such as work organisation (Lengnick-Hall et al., 2009). Strategic HRM theory asserts that the strategic aims of an organisation are a key influence on managerial decisions about which HR practices to adopt but that these decisions may also be influenced by other organisational and institutional factors (Schuler \& Jackson, 1999; Wright \& McMahan, 1992). The results from this paper are in keeping with empirical research supporting this position (Boxall \& Winterton, 2016; Holman et al., 2009; Osterman, 1994) as they provide further evidence to suggest that managers' decisions to adopt HR practices, and their ability to implement particular HR practices, are shaped by the organisational context (i.e., the predominant occupations in the firm) and the firm's institutional context. One implication of this, for example, is that managerial attempts to implement high-involvement HRM (which implies 
high job discretion, Lawler, 1986) may be increasingly difficult for firms operating in a liberal or continental institutional regime.

Despite the strengths of this study, there are a number of limitations which mean that the findings must be treated cautiously. One potential limitation is that the study did not track individuals over time, which would have enabled an assessment of the impact of technical change and institutional change within a job (if appropriate measures were available). However, a disadvantage of tracking individuals is the potential for a high attrition rate, particularly over a period of twenty years, and consequent biases resulting from non-random missing data. Such problems do not occur in this study due to the cohort-based approach, although a disadvantage of this approach is that it reduces the sample size, thereby limiting model complexity and statistical power. Further study limitations concern construct measurement. The binary response categories of the three-item measure of job discretion may reduce the sensitivity of the measure to changes in job discretion and its ability to reflect real differences between groups. This means that changes over time may be less pronounced and differences wrongly specified. However, the similarity of findings between EWCS and other national surveys with regard to differences in job discretion between groups (e.g., occupations) suggests that the response categories of the job discretion measure do not unduly affect the findings (Burr et al., 2003). A further measurement limitation is that the study did not assess the introduction of technical change into a job, nor did it include measures of institutional characteristics. Rather it was assumed that the changes occurring between occupations were a result of technical change, and that the changes occurring between institutional regimes were a result of differences in institutional characteristics. However, as the patterns of change across occupations and institutional regimes were in keeping with theoretical assumptions, this provides some confidence that the changes in job discretion between occupations were largely a result of technical change and that the changes 
in job discretion across institutional regimes were mainly a result of cross-national differences in trade union participation and employment policies. Another limitation is that the study did not fully examine whether trends were consistent across genders, although some studies do suggest that institutions can have a differential impact on the working conditions of men and women (Estevez-Abe, 2005; Robson, Dex, Wilkinson, \& Cortes, 1999; Tomlinson, 2007).

In conclusion, by drawing on RBTC and employment regime theory, this study suggests that job discretion in the European workforce is becoming increasingly polarised between employees in different occupations due to the effects of technical change and between countries as a result of cross-national differences in institutional regimes, specifically that between social democratic and other institutional regimes. This pattern of change in job discretion should be of concern as it implies that the distribution of job quality is becoming less equitable. However, the findings of this study may only apply to job discretion and the extent to which they apply to other working practices is a question for future research.

\section{References}

Acemoglu, D. (2002). 'Technical change, inequality and the labor market'. Journal of Economic Literature, 40, 7-72.

Acemoglu, D., and Autor, D. (2010). Skills, tasks and technologies: Implications for employment and earnings. NBER Working Paper Series.

Allmendinger, J. and Von Den Driesch, E. (2014). Social inequalities in Europe: Facing the challenge (No. P 2014-005). Social Science Research Center Berlin (WZB).

Amable, B. (2003). The diversity of modern capitalism. Oxford: Oxford University Press. Appelbaum, E., Bailey, T, Berg, P., and Kalleberg, A. (2000). Manufacturing advantage. Ithaca, NY: ILR Press. 
Autor, D., Katz, L., and Krueger, A. (1998). 'Computing inequality: Have computers changed the labor market?' Quarterly Journal of Economics, 113, 1169-1214

Autor, D. H., Levy, F., and Murnane, R. J. (2003). 'The skill content of recent technological change: An empirical investigation'. Quarterly Journal of Economics, 118, 1279-1333.

Bechter, B., Brandl, B., and Meardi, G. (2012). 'Sectors or countries? Typologies and levels of analysis in comparative industrial relations'. European Journal of Industrial Relations, 18, 185-202.

Bernerth, J. and Walker, H. J. (2012). 'Reexamining the workplace justice to outcome relationship: Does frame of reference matter?' Journal of Management Studies, 49, 945969.

Boxall, P. and Purcell, J. (2011). Strategy and human resource management. Basingstoke: Palgrave Macmillan.

Boxall, P. and Winterton, J. (2016). Which conditions foster high-involvement work processes? A synthesis of the literature and agenda for research. Economic and Industrial Democracy, DOI: 10.1177/0143831X15599584

Braverman, H. (1974). Labor and monopoly capital: The degradation of work in the twentieth century. NY, Monthly Review Press.

Bresnahan, T. F., Brynjolfsson, E., and Hitt, L. M. (2002). 'Information technology, workplace organization, and the demand for skilled labor: Firm level evidence'. Quarterly Journal of Economics, 117, 339-376.

Brock, E. and Dobbelaere, S. (2006). 'Has international trade affected workers' bargaining power?' Review of World Economics, 127, 233-266.

Brown, M. E. and Treviño, L. K. (2006). 'Ethical leadership: A review and future directions.' The Leadership Quarterly, 17, 595-616. 
Burr, H., Bjorner, J. B., Kristensen, T. S., Tüchsen, F., and Bach, E. (2003). 'Trends in the Danish work environment in 1990-2000 and their associations with labor-force changes.' Scandinavian Journal of Work, Environment and Health, 29, 270-279.

Cappelli, P. (2000). 'A market-driven approach to retaining talent.' Harvard Business Review, 78, 103-11.

Cappelli, P., Bassi, L., Katz, H., Knoke, D., Osterman, P. and Useem, M. (1997). Change at work. New York: Oxford University Press.

Clegg, C. and Spencer, C. (2007). 'A circular and dynamic model of the process of job design'. Journal of Occupational and Organizational Psychology, 80, 321-339.

Cohen-Charash, Y. and Spector, P. E. (2001). 'The role of justice in organizations: A metaanalysis'. Organizational behavior and human decision processes, 86, 278-321.

Cropanzano, R., Bowen, D. E., and Gilliland, S. W. (2007). 'The management of organizational justice.' The Academy of Management Perspectives, 21, 34-48.

Culpepper, P.D. and Thelen, K. (2007). 'Institutions and collective actors in the provision of training: Historical and cross-national comparisons'. In Mayer K.U. and Solga H. (Eds.) Skill formation. Interdisciplinary and cross-national perspectives. New York: Cambridge University Press, 21-49.

Curran, P. J., Obeidat, K., and Losardo, D. (2010). 'Twelve frequently asked questions about growth curve modeling'. Journal of Cognition and Development, 11, 121-136.

Davis, S. (1992). 'Cross-country patterns of changes in relative wages'. NBER Macroeconomic Annual, 86, 239-292.

Deaton, A. (1985). 'Panel data from time series of cross sections'. Journal of Econometrics, 30, 109-126. 
Delbridge, R. (2005). 'Workers under lean manufacturing'. In D. Holman, T. D. Wall, C. Clegg, P. Sparrow and A. Howard (Eds.) The essentials of the new workplace: A guide to the human impact of modern working practices. Chichester, John Wiley, 15-32.

Dobbin, F. and Boychuk, T. (1999). 'National employment systems and job autonomy: Why job autonomy is high in the Nordic countries and low in the United States, Canada, and Australia'. Organization Studies, 20, 257-291.

Doellgast, V. and Greer, I. (2007). 'Vertical disintegration and the disorganization of German industrial relations'. British Journal of Industrial Relations, 45, 55-76.

Eijckelhof, B. H. W., Huysmans, M. A., Bruno Garza, J. L., Blatter, B. M., Van Dieën, J. H., Dennerlein, J. T., and Van Der Beek, A. J. (2013). 'The effects of workplace stressors on muscle activity in the neck-shoulder and forearm muscles during computer work: A systematic review and meta-analysis'. European Journal of Applied Physiology, 113, 2897-2912.

Eriksson-Zetterquist, U., Lindberg, K., and Styhre, A. (2009). 'When the good times are over: professionals encountering new technology'. Human Relations, 62, 1145-1170.

Esping-Andersen, G. (1990). The three worlds of welfare capitalism. Princeton, NJ: Princeton University Press.

Esser, I. and Olsen, K. M. (2012). 'Perceived job quality: Autonomy and job security within a multi-level framework'. European Sociological Review, 28, 443-454.

Estevez-Abe, M. (2005). 'Gender bias in skills and social policies: the varieties of capitalism perspective on sex segregation'. Social Politics, 12, 180-215

Eurofound (2006). Fifteen years of working conditions in the EU: Charting the trends. Publications Office of the European Union, Luxembourg. Eurofound (2007). Fourth European Working Conditions Survey. Publications Office of the European Union, Luxembourg. 
Eurofound (2008). Use of technology and working conditions in the European Union.

Publications Office of the European Union, Luxembourg.

Eurofound (2009). Convergence and divergence of working conditions in Europe: 19902005. Publications Office of the European Union, Luxembourg.

Eurofound (2012a). Fifth European Working Conditions Survey. Publications Office of the European Union, Luxembourg.

Eurofound (2012b). Trends in job quality in Europe. Publications Office of the European Union, Luxembourg.

Eurofound (2013). Work organisation and employee involvement in Europe. Publications Office of the European Union, Luxembourg

Eurofound (2015). Convergence and divergence of job quality in Europe from 1995 to 2010. Publications Office of the European Union, Luxembourg.

European Commission (2008). Industrial Relations in Europe 2008. Brussels, DirectorateGeneral for Employment, Social Affairs, and Equal Opportunities.

Ferrer-i-Carbonell, A., and Frijters, P. (2004). 'How important is methodology for the estimates of the determinants of Happiness?' The Economic Journal, 114, 641-659.

Ferragina, E., Seeleib-Kaiser, M., and Spreckelsen, T. (2014). 'The four worlds of 'welfare reality' - social risks and outcomes in Europe'. Social Policy and Society, 14, 287-307.

Finegold, D. and Soskice, D. (1988). 'The failure of training in Britain: Analysis and prescription'. Oxford Review of Economic Policy, 4, 21-53.

Gallie, D. (2000). The quality of working life: Is Scandinavia different? Working paper 2000/154. http://www.march.es/ceacs/publicaciones/working/archivos/2000_154.pdf

Gallie, D. (2007). Employment regimes and the quality of work. Oxford: Oxford University Press. 
Gallie, D. (2013). Economic crisis, quality of work, and social integration: The European experience. Oxford: Oxford University Press.

Gallie, D., Felstead, A., and Green, F. (2004). 'Changing patterns of task discretion in Britain'. Work, Employment \& Society, 18, 243-266.

Goergen, M., Brewster, C. and Wood, G. (2009). 'Corporate governance and training'. Journal of Industrial Relations, 51, 459-487.

Goos, M., Manning, A., and Salomons, A. (2009). 'Job polarization in Europe'. The American Economic Review, 99, 58-63.

Goos, M., Manning, A., and Salomons, A. (2011). Explaining job polarization: the roles of technology, offshoring and institutions. Center for Economic Studies Discussions Paper Series (DPS) 11.34.

Green, F. (2006). Demanding work. The paradox of job quality in the affluent economy. Princeton, NJ: Princeton University Press.

Green, F. (2009). Employee involvement, technology and job tasks (No. 326). National Institute of Economic and Social Research.

Green, F., Mostafa, T., Parent-Thirion, A., Vermeylen, G., Van Houten, G., Biletta, I., and Lyly-Yrjanainen, M. (2013). 'Is job quality becoming more unequal?' Industrial \& Labor Relations Review, 66, 753-784.

Greenan N., Kalugina E., and Walkowiak, E. (2013). 'Has the quality of working life improved in the EU-15 between 1995 and 2005?' Industrial and Corporate Change, 22, 130.

Grimm, K.J. and Ram, N. (2009). 'Nonlinear growth models in Mplus and SAS'. Structural Equation Modeling, 16, 676-701.

Gustavsen, B. (2007). 'Work organization and 'The Scandinavian Model'”. Economic and Industrial Democracy, 28, 650-671. 
Guy, F. and Skott, P. (2008). 'Information and communications technologies, coordination and control, and the distribution of income'. Journal of Income Distribution, 17, 71-92.

Hall, P.A. and Soskice, D. (2001). 'An introduction to varieties of capitalism'. In D. Soskice (Ed.) Varieties of capitalism: The institutional foundation of comparative advantage. New York: Oxford University Press, 1-70.

Hempell, T., and Zwick, T. (2005). Technology use, organisational flexibility and innovation: Evidence for Germany. ZEW Discussion Papers, No. 05-57.

Holman, D. (2005). 'Call Centres'. In Holman, D., Wall, T.D., Clegg, C., Sparrow, P., and Howard, A. (2005). (Eds) Essentials of the new work place: A guide to the human impact of modern working practices. Chichester: John Wiley and Sons, 111-131.

Holman, D. (2013). 'Job types and job quality in Europe'. Human Relations, 66, 475-502.

Holman, D., Frenkel, S., Sørensen, O. and Wood, S. (2009). 'Work design variation and outcome in call centres: Strategic choice and institutional explanations'. Industrial and Labor Relations Review, 62, 510-532.

Holman, D. J. and Wall, T. D. (2002). 'Work characteristics, learning-related outcomes, and strain: a test of competing direct effects, mediated, and moderated models'. Journal of Occupational Health Psychology, 7, 283.

Holman, D., Wall, T.D., Clegg, C., Sparrow, P., and Howard, A. (2005). (Eds) Essentials of the New Work Place: A guide to the human impact of modern working practices. Chichester: John Wiley and Sons.

Hu, L. and Bentler, P.M. (1999). 'Cutoff criteria for fit indexes in covariance structure analysis: Conventional criteria versus new alternatives'. Structural Equation Modelling, 6, $1-55$. 
Humphrey, S. E., Nahrgang, J. D., and Morgeson, F. P. (2007). 'Integrating motivational, social, and contextual work design features: a meta-analytic summary and theoretical extension of the work design literature'. Journal of Applied Psychology, 92, 1332-1356.

Hyman, R. (2001). Understanding European trade unionism: Between market, class and society. London: Sage.

ILO (2012). International Standard Classification of Occupations. International Labour Organization: Geneva.

Jackson, P. R., Wall, T. D., Martin, R., and Davids, K. (1993). 'New measures of job control, cognitive demand, and production responsibility'. Journal of Applied Psychology, 78, 753762.

Jermier, J. M., Knights, D. E., and Nord, W. R. (1994). Resistance and power in organizations. London: Routledge.

Kalleberg, A. L. (1977). 'Work values and job rewards: A theory of job satisfaction'. American Sociological Review, 41, 124-143.

Kalleberg, A. (2011). Good jobs, bad jobs: The rise of polarized and precarious employment systems in the United States, 1970s-2000s. New York, NY: Russell Sage Foundation

Kaplan, D. (2008). Structural equation modeling: Foundations and extensions. London: Sage.

Karasek, R., and Theorell, T. (1990). Healthy work: Stress, productivity, and the reconstruction of working life. New York: Basic Books.

Kelley, M. R. (1989). 'Unionization and job design under programmable automation'. Industrial Relations, 28, 174-187.

Kepes, S., and Delery, J. (2006). 'Designing effective HRM systems: The issue of HRM strategy'. In R. J. Burke, and C. L. Cooper (Eds.). The human resources revolution: Why putting people first matters. Amsterdam, NL: Elsevier, 55-76. 
Knights, D., Willmott, H., and Collinson, D. L. (1985). Job redesign: Critical perspectives on the labour process. Aldershot: Gower Publishing Company.

Korpi, W. (2006). 'Power resources and employer-centered approaches in explanations of welfare states and varieties of capitalism. Protagonists, consenters and antagonists'. World Politics, 58, 167-206.

Kristensen, P.H. and Lilja, K, (2010). New modes of globalizing: Experimentalist forms of economic organization and enabling welfare institutions. Lessons from the Nordic countries and Slovenia. Final report of project Transnational learning through local experimenting (Translearn), EU-funded 6th Framework program.

Lawler, E. E. (1986). High-involvement management. Participative strategies for improving organizational performance. Jossey-Bass: San Francisco.

Lengnick-Hall, M. L., Lengnick-Hall, C. A., Andrade, L. S., and Drake, B. (2009). 'Strategic human resource management: The evolution of the field'. Human Resource Management Review, 19, 64-85.

Lepak, D. P. and Snell, S. A. (1999). 'The human resource architecture: Toward a theory of human capital allocation and development'.' Academy of Management Review, 24, 31-48.

Lopes, H., Lagoa, S., and Calapez, T. (2014). 'Work autonomy, work pressure, and job satisfaction: An analysis of European Union countries'. Economic and Labour Relations Review, 25, 306-326.

Marcolin, L., Miroudot, S. and Squicciarini, M. (2016). Routine jobs, employment and technological innovation in global value chains. OECD Science, Technology and Industry Working Papers, 2016/01, OECD Publishing, Paris.

Marescaux, E., De Winne, S., and Sels, L. (2013). 'HR practices and affective organisational commitment: (when) does HR differentiation pay off?' Human Resource Management Journal, 23, 329-345. 
McLaughlin, C. (2009). 'The productivity-enhancing impacts of the minimum wage: Lessons from Denmark and New Zealand'. British Journal of Industrial Relations, 47, 327-348.

Milgrom, P. and Roberts, J. (1990). 'The economics of modern manufacturing: Technology, strategy, and organization'. The American Economic Review, 80, 511-528.

Maselli, I. (2012). 'The evolving supply and demand of skills in the labour market'. Intereconomics, 47, 22-30.

Mishel, L., Schmitt, J., and Shierholz, H. (2013). Assessing the job polarization explanation of growing wage inequality. Economic Policy Institute. Working Paper.

Molina, O. and Rhodes, M. (2007). 'The political economy of adjustment in mixed market economies: A study of Spain and Italy'. In B. Hancké, M. Rhodes and M. Thatcher (Eds.) Beyond varieties of capitalism. Oxford: Oxford University Press, 223-252.

Mouw, T. and Kalleberg, A. L. (2010). 'Occupations and the structure of wage inequality in the United States, 1980s to 2000s'. American Sociological Review, 75, 402-431.

Muthén, L.K. and Muthén, B.O. (2004). Mplus: Statistical analysis with latent variables, users guide. Los Angeles: Muthén \& Muthén.

Nelson, R. R. and Phelps, E. S. (1966). 'Investment in humans, technological diffusion, and economic growth'. The American Economic Review, 56, 69-75.

Olsen, K. M., Kalleberg, A. L., and Nesheim, T. (2010). 'Perceived job quality in the United States, Great Britain, Norway and West Germany, 1989-2005'. European Journal of Industrial Relations, 16, 221-240.

Osterman, P. (1994). 'How common is workplace transformation and who adopts it?' Industrial and Labor Relations Review, 47, 173-88.

Parker, S.K. and Wall, T.D. (1998). Job and work design: Organizing work to promote wellbeing and effectiveness. London: Sage. 
Pfeffer, J. and Konrad, A. M. (1991). 'The effects of individual power on earnings'. Work and Occupations, 18, $385-414$.

Prais, S.J., Jarvis, V. and Wagner, K. (1989). 'Productivity and vocational skills in services in Britain and Germany: Hotels'. National Institute Economic Review, 130, 52-74.

Robson, P., Dex, S., Wilkinson, F., and Cortes, O. S. (1999). 'Low pay, labour market institutions, gender and part-time work: Cross-national comparisons'. European Journal of Industrial Relations, 5, 187-207.

Rubery, J. and Grimshaw, D. (2001). 'ICTs and employment: The problem of job quality. International Labour Review', 140, 165-192.

Schuler, R. S. and Jackson, S. E. (1987). 'Linking competitive strategies with human resource management practices'. Academy of Management Executive, 1, 207-219.

Skarlicki, D. P. and Folger, R. (1997). 'Retaliation in the workplace: The roles of distributive, procedural, and interactional justice'. Journal of Applied Psychology, 82, 434-443.

Skott, P. and Guy, F. (2007). 'A model of power-biased technological change'. Economics Letters, 95, 124-131.

Sørensen, O. H., Doellgast, V., and Bojesen, A. (2014). 'Intermediary cooperative associations and the institutionalization of participative work practices: A case study in the Danish public sector'. Economic and Industrial Democracy, 36, 701-725.

Sørensen, O. H. and Weinkopf, C. (2009). 'Pay and working conditions in finance and utility call centres in Denmark and Germany'. European Journal of Industrial Relations, 15, 395416.

Spitz-Oener, A. (2006). 'Technical change, job tasks, and rising educational demands: Looking outside the wage structure', Journal of Labor Economics, 24, 235-270. Spitz-Oener, A. (2008). 'The returns to pencil use revisited'. Industrial \& Labor Relations Review, 61, 502-517. 
Stahl, G. K. and Björkman, I. (2006). Handbook of research in international human resource management. Cheltenham: Edward Elgar.

Stiglitz, J. E. (2013). The price of inequality. London: Penguin,

Tåhlin, M. (2007). 'Skills and wages in European labour markets: Structure and change'. In D Gallie (Ed.) Employment Regimes and the Quality of Work. Oxford: Oxford University Press, 35-76.

Tims, M., Bakker, A. B., and Derks, D. (2013). 'The impact of job crafting on job demands, job resources, and well-being'. Journal of Occupational Health Psychology, 18, 230-240.

Tomlinson, J. (2007). 'Employment regulation, welfare and gender regimes: A comparative analysis of women's working-time patterns and work-life balance in the UK and the US'. International Journal of Human Resource Management, 18, 401-415

Tregaskis, O. and Brewster, C. (2006). 'Converging or diverging? A comparative analysis of trends in contingent employment practice in Europe over a decade'. Journal of International Business Studies, 37, 111-126.

Verbeek, M. and Vella, F. (2005). 'Estimating Dynamic Models from Repeated CrossSections', Journal of Econometrics, 127, 83-102.

Violante, G. F. (2008). 'Skill-biased technical change'. In S. Durlauf and L. Blume (Eds.). The New Palgrave Dictionary of Economics. London: Palgrave. http://www.econ.nyu.edu/user/violante/Books/sbtc_january16.pdf

Wallerstein, M. (1999). 'Wage-setting institutions and pay inequality in advanced industrial societies'. American Journal of Political Science, 43, 649-680.

Wright, P. and McMahan, G. C. (1992). 'Theoretical perspectives for strategic human resource management'. Journal of Management, 18, 295-320.

Wrzesniewski, A. and Dutton, J. E. (2001). 'Crafting a job: Revisioning employees as active crafters of their work'. Academy of Management Review, 26, 179-201. 
Table 1. Patterns of convergence and divergence in work and employment conditions

\begin{tabular}{|c|c|c|c|c|c|c|}
\hline & \multicolumn{6}{|c|}{ Convergence and Divergence } \\
\hline & \multicolumn{2}{|r|}{ Convergence } & \multicolumn{2}{|c|}{ No Differences } & \multicolumn{2}{|r|}{ Divergence } \\
\hline $\begin{array}{l}\text { General } \\
\text { Improvement }\end{array}$ & & $\begin{array}{l}\text { Harmonised } \\
\text { Improvement } \\
\text { Differential rates } \\
\text { of improvement in } \\
\text { groups, faster } \\
\text { growth at bottom }\end{array}$ & $\Longrightarrow$ & $\begin{array}{l}\text { Even } \\
\text { Progress }\end{array}$ & & $\begin{array}{l}\text { Polarized } \\
\text { Improvement } \\
\text { Differential rates } \\
\text { of improvement } \\
\text { groups, faster } \\
\text { growth at top }\end{array}$ \\
\hline No Change & $\longrightarrow$ & $\begin{array}{l}\text { "Pure" } \\
\text { Harmonisation }\end{array}$ & $\longrightarrow$ & Static & & $\begin{array}{l}\text { "Pure" } \\
\text { Polarisation }\end{array}$ \\
\hline $\begin{array}{l}\text { General } \\
\text { Decline }\end{array}$ & & $\begin{array}{l}\text { Harmonised } \\
\text { Decline } \\
\text { Differential rates } \\
\text { of decline in } \\
\text { groups, faster } \\
\text { decline at top }\end{array}$ & $\longrightarrow$ & $\begin{array}{l}\text { Even } \\
\text { Decline }\end{array}$ & $x$ & $\begin{array}{l}\text { Polarized Decline } \\
\text { Differential rates } \\
\text { of decline in } \\
\text { groups, faster } \\
\text { decline at bottom }\end{array}$ \\
\hline
\end{tabular}

(From Eurofound, 2015) 
Table 2. Mean scores and correlations between main study variables $(n=135)$

\begin{tabular}{|c|c|c|c|c|c|c|c|c|c|c|c|c|c|c|}
\hline & & Mean & 1 & 2 & 3 & 4 & 5 & 6 & 7 & 8 & 9 & 10 & 11 & 12 \\
\hline 1 & Job Discretion 1995 & 72.17 & - & & & & & & & & & & & \\
\hline 2 & Job Discretion 2000 & 69.02 & $.81 * *$ & - & & & & & & & & & & \\
\hline 3 & Job Discretion 2005 & 69.52 & $.79 * *$ & $.80 * *$ & - & & & & & & & & & \\
\hline 4 & $\begin{array}{l}\text { Job Discretion } 2010 \\
\text { Occupation }\end{array}$ & 69.49 & $.83 * *$ & $.85 * *$ & $.83 * *$ & - & & & & & & & & \\
\hline 5 & High-Skill & 0.35 & $.60 * *$ & $.69 * *$ & $.62 * *$ & $.64 * *$ & - & & & & & & & \\
\hline 6 & Non-Routine Clerical & 0.35 & $.60 * *$ & $.68 * *$ & $.62 * *$ & $.64 * *$ & $1.00 * *$ & - & & & & & & \\
\hline 7 & Routine Clerical & 0.29 & -.03 & -.16 & -.16 & $-.26 * *$ & $-.48 * *$ & $-.48 * *$ & - & & & & & \\
\hline 8 & Non-Routine Manual & 0.14 & $-.23 * *$ & -.16 & $-.21 *$ & -.16 & $-.33 * *$ & $-.33 * *$ & $-.26 * *$ & - & & & & \\
\hline 9 & $\begin{array}{l}\text { Routine Manual } \\
\text { Institutional Regime }\end{array}$ & 0.21 & $-.48 * *$ & $-.50 * *$ & $-.37 * *$ & $-.33 * *$ & $-.34 * *$ & $-.34 * *$ & $-.33 * *$ & $.20 *$ & - & & & \\
\hline 10 & Social Democratic & 0.18 & $.22 * *$ & $.29 * *$ & $.36 * *$ & $.38 * *$ & .08 & .08 & -.04 & -.03 & -.04 & - & & \\
\hline 11 & Continental & 0.43 & -.05 & .01 & -.04 & -.14 & .00 & .00 & .05 & -.01 & -.05 & $-.42 * *$ & - & \\
\hline 12 & Liberal & 0.12 & -.02 & -.08 & -.06 & -.13 & -.01 & -.01 & .00 & -.02 & .03 & $-.18^{*}$ & $-.34 * *$ & - \\
\hline 13 & Southern European & 0.24 & -.11 & $-.21 *$ & $-.22 *$ & -.08 & -.07 & -.07 & -.02 & .05 & .07 & $-.27 * *$ & $-.50 * *$ & $-.22 * *$ \\
\hline
\end{tabular}


Table 3. Adjusted mean job discretion score for occupational groups and institutional regime by time $(\mathbf{n}=135)$

\begin{tabular}{lcccc}
\hline & $\mathbf{1 9 9 5}$ & $\mathbf{2 0 0 0}$ & $\mathbf{2 0 0 5}$ & $\mathbf{2 0 1 0}$ \\
\hline $\begin{array}{l}\text { Occupational Groups } \\
\text { High-skill }\end{array}$ & 81.49 & 82.90 & 79.78 & 80.61 \\
$\quad$ Low-skill & 66.22 & 61.04 & 63.16 & 62.85 \\
Non-Routine Clerical & 80.65 & 82.12 & 79.44 & 80.28 \\
$\quad$ Routine Clerical & 73.47 & 67.46 & 65.61 & 64.93 \\
$\quad$ Non-Routine Manual & 66.35 & 63.23 & 66.33 & 67.64 \\
$\quad$ Routine Manual & 57.85 & 52.39 & 58.48 & 57.63 \\
Institutional Regime & & & & \\
$\quad$ Social Democratic & 76.28 & 75.81 & 77.64 & 77.73 \\
$\quad$ Continental & 71.00 & 69.21 & 67.75 & 67.58 \\
$\quad$ Liberal & 73.11 & 67.26 & 69.07 & 66.36 \\
$\quad$ Southern European & 69.19 & 64.65 & 65.55 & 67.65 \\
\hline
\end{tabular}


Table 4. Results of latent growth models

\begin{tabular}{|c|c|c|c|c|c|c|c|c|c|c|c|c|}
\hline & \multicolumn{2}{|c|}{ Baseline } & \multicolumn{2}{|c|}{ Occupation: High Skill } & \multicolumn{4}{|c|}{ Occupation by Skill and Role } & \multicolumn{4}{|c|}{ Institutional Regimes } \\
\hline & $\mathbf{1 a}$ & $\mathbf{1 b}$ & $2 \mathbf{a}$ & $2 \mathbf{b}$ & $\mathbf{3 a}$ & $3 \mathbf{b}$ & 3c & 3d & $\mathbf{4 a}$ & $4 b$ & $4 c$ & 4d \\
\hline & $\begin{array}{c}\text { Baseline } \\
\text { Model }\end{array}$ & $\begin{array}{c}\text { Baseline } \\
+ \\
\text { Controls }\end{array}$ & $\begin{array}{l}\text { High } \\
\text { Skill }\end{array}$ & $\begin{array}{l}\text { High skill + } \\
\text { Institutions }\end{array}$ & $\begin{array}{c}\text { Non- } \\
\text { Routine } \\
\text { Clerical }\end{array}$ & $\begin{array}{l}\text { Routine } \\
\text { Clerical }\end{array}$ & $\begin{array}{c}\text { Non- } \\
\text { Routine } \\
\text { Manual }\end{array}$ & $\begin{array}{l}\text { Routine } \\
\text { Manual }\end{array}$ & Nordic & Cont. & Liberal & Sth. Eu. \\
\hline Intercept & $71.44 *$ & 27.51 & $24.94 *$ & $64.82 * *$ & $50.56 * *$ & $40.12 * *$ & $32.93 * *$ & $26.77 * *$ & $50.22 * *$ & $36.85 * *$ & $29.53 * *$ & $19.97 * *$ \\
\hline Slope & $-1.13^{*}$ & -1.99 & -3.24 & -2.47 & -10.27 & $-12.06 \dagger$ & $-8.83 \dagger$ & -8.94 & -2.89 & -7.73 & -5.48 & -3.79 \\
\hline$s$ with $i$ & 2.10 & -15.53 & -4.42 & -1.87 & 1.07 & 1.07 & 1.07 & 1.07 & -0.11 & -0.11 & -0.11 & -0.11 \\
\hline High-Skill Occ. & & & $16.57 * *$ & $3.55 * *$ & & & & & & & & \\
\hline Non-Routine Clerical & & & & & - & $10.43 * *$ & $17.63 * *$ & $23.78 * *$ & - & $9.52 * *$ & $16.83^{* *}$ & $23.15^{* *}$ \\
\hline Routine Clerical & & & & & $-10.43 * *$ & - & $-7.19 \dagger$ & $13.35 * *$ & $-9.52 * *$ & - & $7.31 *$ & $13.62 * *$ \\
\hline Non-Routine Manual & & & & & $-17.63 * *$ & $-7.19 \dagger$ & - & $6.16 * *$ & $-16.83 * *$ & $-7.31 *$ & - & $6.31 *$ \\
\hline Routine Manual & & & & & $-23.78 * *$ & $-13.35 * *$ & $-6.16^{*}$ & - & $-23.15^{* *}$ & $-13.62 * *$ & $-6.31^{*}$ & - \\
\hline Nordic & & & & - & & & & & - & $3.85^{*}$ & $3.96^{*}$ & $7.10 * *$ \\
\hline Continental & & & & $-4.32 *$ & & & & & $-3.85^{*}$ & - & .01 & $3.25^{*}$ \\
\hline Liberal & & & & $-4.68 *$ & & & & & $-3.96 *$ & -.01 & - & $3.24 \dagger$ \\
\hline \multicolumn{13}{|l|}{ Slope } \\
\hline High-Skill Occ. & & & .16 & .14 & & & & & & & & \\
\hline Non-Routine Clerical & & & & & - & $1.93 \dagger$ & -1.44 & -1.33 & - & $2.80 *$ & -.81 & -1.07 \\
\hline Routine Clerical & & & & & $-1.93 \dagger$ & - & $-3.36 \dagger$ & $-3.26 *$ & $-2.80 *$ & - & $-3.09 *$ & $-3.35 * *$ \\
\hline Non-Routine Manual & & & & & 1.44 & $3.36 \dagger$ & - & .10 & .81 & $3.09 *$ & - & .26 \\
\hline Routine Manual & & & & & 1.33 & $3.26^{*}$ & .10 & - & 1.07 & $3.35 * *$ & -.26 & - \\
\hline Nordic & & & & - & & & & & - & $2.56^{* *}$ & $3.40 * *$ & $1.92 * *$ \\
\hline Continental & & & & $-2.47 * *$ & & & & & $-2.56^{* *}$ & - & .84 & -.64 \\
\hline Liberal & & & & $-3.22 * *$ & & & & & $-3.40 * *$ & -.84 & - & -1.48 \\
\hline Sth European & & & & $-1.89 *$ & & & & & $-1.92 *$ & .64 & 1.48 & - \\
\hline $\mathbf{R}^{2}$ Intercept \% & - & - & 50 & 67 & 62 & 62 & 62 & 62 & 66 & 66 & 66 & 66 \\
\hline $\mathbf{R}^{2}$ Slope $\%$ & - & - & 0 & 45 & 43 & 43 & 43 & 43 & 69 & 69 & 69 & 69 \\
\hline
\end{tabular}


Figure 1. Trends in job discretion for occupational groups and institutional regimes $(n=135)$

1a. High and Low-skill Occupations

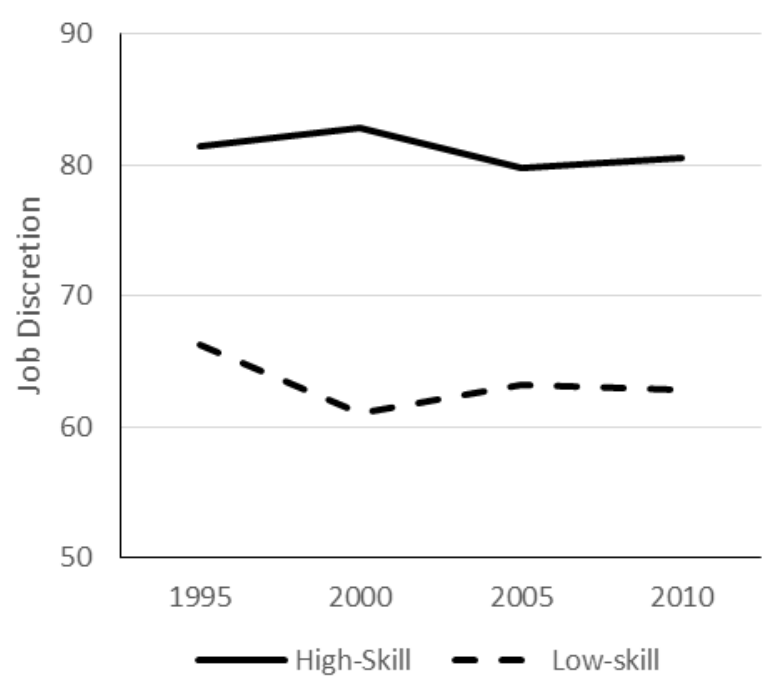

1b. Occupations by Skill and Task Type

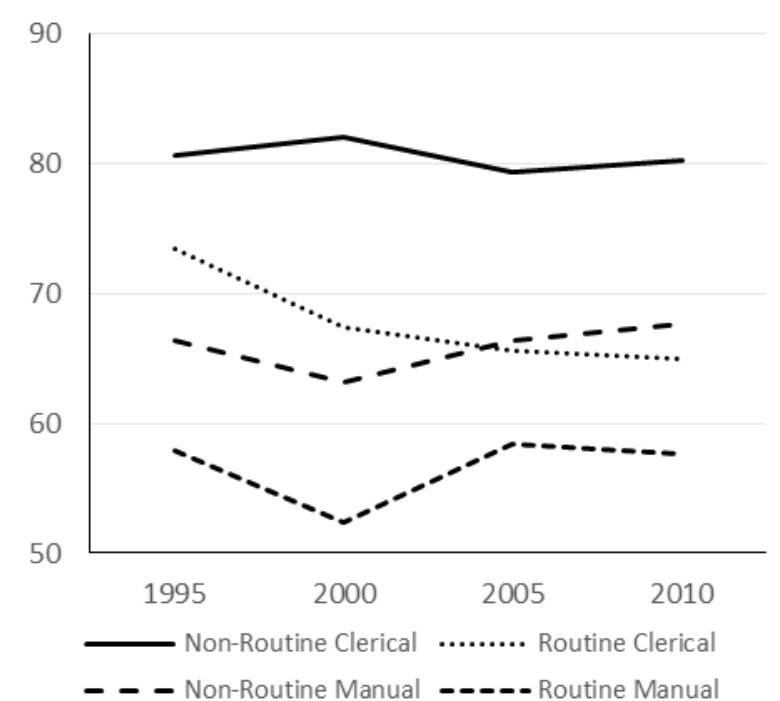

1c. Institutional Regime

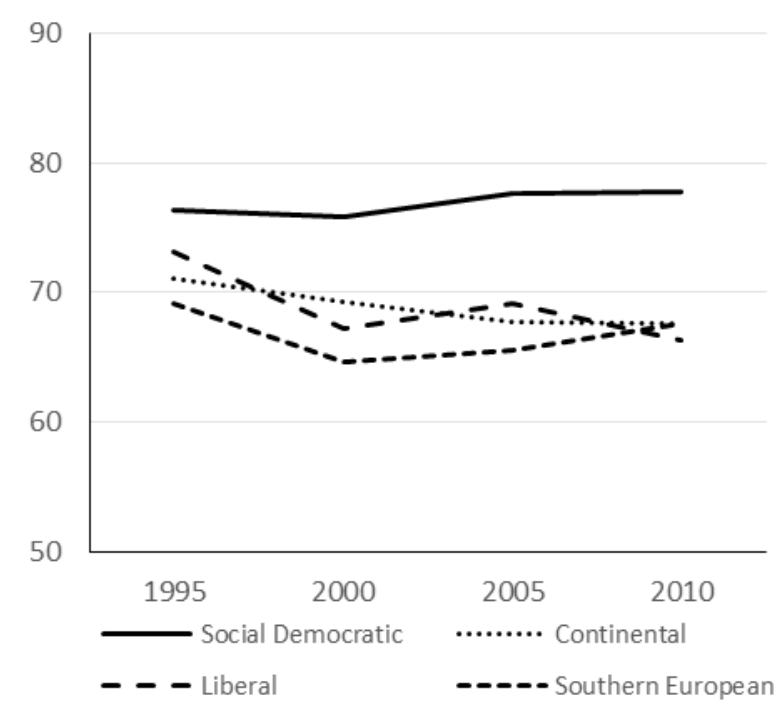


Figure 2. Trends in mean scores of job discretion by occupational group and institutional regime $(\mathbf{n}=135)$

2a. Social Democratic

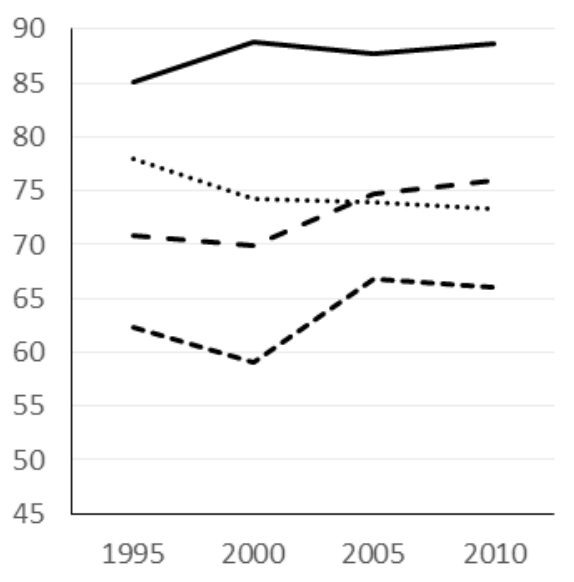

2b. Continental

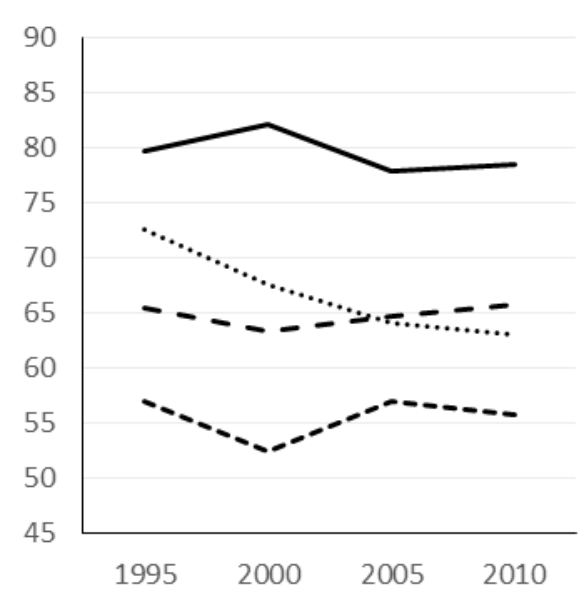

Non-Routine Clerical

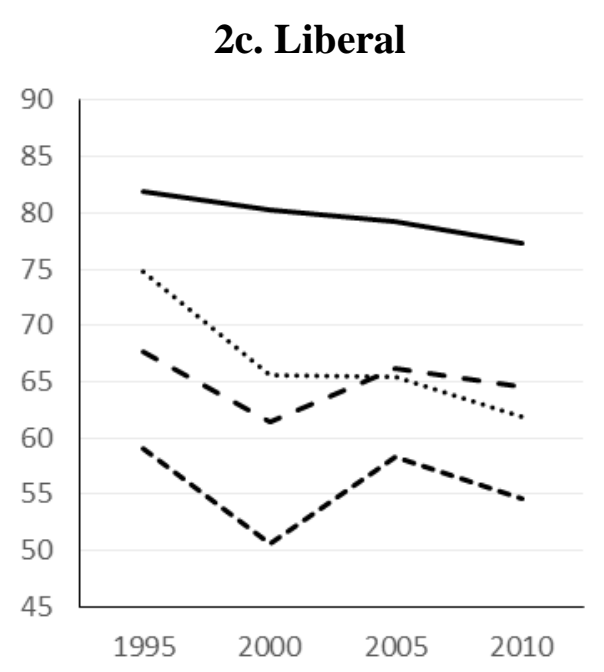

Non-Routine Manual - - - 2d. Southern European

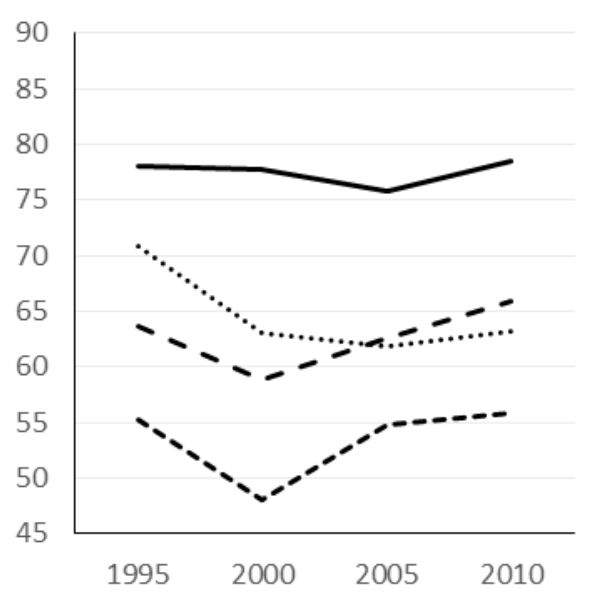

Routine Manual----- 


\section{Notes}

'The EWCS has been conducted every five years from 1990 among EU member states. A stratified and clustered design with a 'random walk' is used to obtain a representative sample of employees in each country.

ii The EU-15 includes Austria, Denmark, Finland, France, Greece, Germany, Ireland, Italy, Luxembourg, Netherlands, Portugal, Spain, Sweden and the United Kingdom.

iii For simplicity of exposition we refer to all non-manual occupations as clerical occupations. When referring to clerical occupations we therefore include managerial, professional and technical occupations, as well as clerks and service and sales roles. We use this label to avoid using a cumbersome double negative (i.e., non-routine non-manual occupations) when referring to managerial, professional and technical occupations.

${ }^{\text {iv }}$ In 1995, within the EU-15, job discretion was highest in non-routine clerical occupations and gets progressively lower in routine clerical, non-routine manual and routine manual occupations (see Table 1b). 